\title{
Immigrants in Northern nature - Environmental biographies through photo elicitation
}

Seija Tuulentie, Natural Resources Institute Finland

\section{Introduction}

A picture of a white-tailed eagle reminds one of one's grandfather who raised hunting falcons. An owl peeping out from a nesting box raises various associations. One associates it with the will to set up a home, and for another it is like a gaze to the future and its problems. For a third, the owl is seen simply as an emblem of a beautiful forest and the will to observe birds. Pictures of domestic animals present memories of nomadism of the family in their country of origin.

In the project 'Polut' ('Paths'), immigrants were asked to choose one or two of their favorite images from a wide array of nature photos and to explain why they chose the ones they did. The basic assumption was that their mobility affects their choices and that the nature of their country of origin would be present in their relationship to their new home country's nature. Although immigrants' non-voluntary mobility is not similar to touristic mobility, the nature of the new country appears to be the same for both groups in many ways. The practice of walking in a forest or finding one's way requires in both cases skills and knowledge which they have not been learned in childhood. Many natural phenomena also raise admiration, hesitation or even fear both among immigrants and tourists. In addition, the touristic images of the new country are widely distributed and familiar both to immigrants and tourists.

The 'Polut' project was based on the notion that even those immigrants originally from different countries in Africa, Asia and South America who had lived in northern Finland for many years did not have much of a connection to the natural environments of their new home country. Most of the participants had, however, lived only a short time in the north, and their relationships to nature might resemble even more that of the tourists, and the images of nature might be only those offered by tourism marketing material. The official integration training of immigrants has concentrated on issues such as adaptation to society and language learning. At the same time, being in nature and using natural products, such as berries, mushrooms and fish, 
Seija Tuulentie

form an extremely important part of the lifestyle of the citizens in the north. The 'Polut' project was carried out during 2016-2019, led by the Lapland University of Applied Sciences and funded by the European Social Fund.

The focus of this research note is on analysing different dimensions of the photo choices from the perspective of immigrants' relationships to nature. How personal environmental history is reflected in the choices and narratives is also discussed.

\section{The specificity of immigrants' relationships to nature}

There are many ways to evaluate the human-nature relationship. For example, it can be emphasised that humans are part of nature (Flint, Kunze, Muhar, Yoshida, \& Penker, 2013; Willamo, 2005), or the environment can be seen as a continuum from untouched nature to the man-made environment and constructions (Rossi, 2010). For research purposes, there is a reason to investigate the relationship to nature, at least to some extent, as a separate part of human life. Here nature is understood widely as diverse environments and rural and nature-based livelihoods as part of this relationship.

Immigrants' history of moving from one culture to another makes their relationship to nature especially interesting. Often an individual takes his or her environment and relationship to it as given - a question which does not have to be evaluated consciously and explicitly. A visitor, outsider or tourist encounters an environment which is new to him/her. Instead of living it, they want to see something new, strange and changing (Karjalainen, 1987, cited in Rossi, 2010). This new then mirrors the old.

As Rossi (2010) states, there is a need to emphasise the individual's lifelong environmental (or nature) relationship, which can be called an environmental biography or an individual's environmental history. Many immigrants also have experiences of other environments than those of their countries of origin or their present home country in that many have spent years or even decades in refugee camps, for example. Thus, the entire life and all stages and difficulties of the migration history are part of their relationship to nature.

Since immigrants have been brought to a new environment, they have a specific need to create a relationship with their new home. Siim (2006) has noted that nature is one important element in this process. However, natural environments can be something that are not meant for all. Laura Huttunen (2002) has collected immigrants' life stories in Finland, and in those they describe how white Finns seem to belong self-evidently to a place and use decisive power regarding those who do not belong (see also Bujis, Elands, \& Langers, 2009). Although nature environments can give comfort, protection and a place for social interaction (Faehnle, Jokinen, Karlin, \& Lyytimäki, 2010; Gentin, 2011), some studies have noted that they are not especially good places to meet new people (Stodolska, Peters, Horolets, 2017) and they can be even negative places - strange, frightening or forbidding (Pitkänen et al., 2017). Some studies have also noted that 'passive' recreational use modes, such as picnics, relaxing and resting are more important to immigrants than those active ones (Özgüner, 2011), and that many immigrants prefer treated landscapes rather than wild or wilderness nature (Buijs et al., 2009; Gentin, 2011). 
From the point of view of integration, it is important that immigrants become acquainted with the idea of the northern relationships to nature and are able to use nature in similar ways to those who have their origins in Nordic countries where nature is an important part of local culture (Pitkänen et al, 2017). Northern relationships to nature can be seen as a mixture of functionality, utilisation and a source of experience and well-being. Thus, many people go to nature to exercise, to collect natural products or to recover - or they do all three of these activities.

\section{Photos as interview stimuli}

In the 'Polut' project, nature photos were used as stimuli in interviews. With the aid of the selected photos, the participants' relationships to nature throughout the course of their lives were discussed. Photo elicitation in interviews is based on the idea that it is possible to use images as bridges between worlds that are culturally distinct, and to notice how differently people see things in the same photos and how photos can be related to diverse contexts (Harper, 2002).

In the 'Polut' project, eight groups participated in photo-based discussions at the beginning of the series of group meetings. Altogether, 63 people from 13 different countries of origin in Africa, Asia, Russia and South America participated in these initial interviews. 32 of the participants were females and 31 males. Eight of the interviewees had come to Finland before 2014 and 55 after that. The stimuli photos were pictures from magazines and newspapers. The interviewees selected mainly one picture, although some wanted to have two and even three pictures. The selection of photos included 154 photos, of which 124 were taken in summer, 21 in winter and 8 were clearly autumn photos. The main theme was people in nature, numbering 64 photos (Table 1). Many of these photos presented different kinds of activities from kayaking and cycling to fishing and berry-picking.

Table 1. Numbers of offered and selected photos and their relative amounts.

\begin{tabular}{lcc} 
THEME OF THE PHOTOS & $\begin{array}{c}\text { WHOLE SELECTION, } \\
\text { NUMBER (\%) }\end{array}$ & $\begin{array}{c}\text { SELECTED, } \\
\text { NUMBER (\%) }\end{array}$ \\
\hline People in nature & $64(41 \%)$ & $20(26 \%)$ \\
\hline Nature without humans & $43(28 \%)$ & $25(32 \%)$ \\
\hline Domestic animals (with or without humans) & $17(11 \%)$ & $9(12 \%)$ \\
\hline $\begin{array}{l}\text { Animals in nature (incl. semi-domesticated } \\
\text { reindeer) }\end{array}$ & $15(10 \%)$ & $12(15 \%)$ \\
\hline $\begin{array}{l}\text { Constructions, parks, means of } \\
\text { transportation (ships, boats, etc.) }\end{array}$ & $15(10 \%)$ & $78(100 \%)$ \\
\hline \begin{tabular}{l} 
In total \\
\hline
\end{tabular}
\end{tabular}


The interviewees did not use much time to choose their favorite photo. The photos were on a table and the interviewees went to select one or several pictures which, at first glance, appealed to them and somehow illustrated their relationship to nature. Pictures of animals and constructions were slightly overrepresented in the selections (Table 1). Additionally, pictures without people were selected relatively more than pictures offered.

The interviewees were first asked to tell which country and what kind of area they are from and how long they have been in Finland. After that the reasons to select the photo in question were discussed. In addition the meaning of nature in their country of origin was discussed. Then the discussion proceeded to their experiences of Finnish nature and their interests in nature activities. This discussion cannot be regarded as creating a deep environmental biography but relationships to nature in connection to different life stages arose.

In this analysis, the contents of the pictures have been divided, based on three observations: firstly, how the country of origin is revealed in the choice; secondly, what kinds of experiences are related to nature, and thirdly how nature reflects the state of mind. These categories are based on the narratives the interviewees used in describing their choices.

\section{Photos with memories of the country of origin}

The country of origin is present in choices in many ways. Photos presenting domestic animals and gardens or very green landscape were especially chosen, since they contained memories of home. The greenness of the country of origin was especially emphasized in the narratives. For example, one interviewee said, "we had this kind of nature in Ethiopia, a lot of green. I miss the green environment just because it existed in my home country".

Some choices fell on a specific picture as it evoked memories of people. One interviewee from Afghanistan said, "I was born in Kandahar in Afghanistan, everything was good there, since the whole family lived there". A remarkable part of the choices, ten photos, focused on pictures of domestic animals, sheep, horses and cows, or fishing. These choices were related to the fact that the family had been nomadic or fishermen, or that animals had in some other way been an important part of life. A notion was made that it is rare to see domestic animals in Finland.

Some photos served for comparing the situation in the country of origin and in the present home country. Differences, for example in safety and peacefulness, were pointed out: Walking in a forest in Lapland felt safe contrary to walking in the country of origin. Additionally, it was mentioned that in the parks of the country of origin or in the refugee camp it was not peaceful because of the crowds or because of the loss of a general feeling of safety.

\section{Nature as an experience and a place for action}

Many of the photo choices were justified by the natural environment itself. The interviewees said, for example, that they liked the forest, trees and being in a forest in general, or that they liked beautiful scenery, being in nature and observing animals.

Northern nature was present in many ways. One interviewee stated that "when living here in the north, nature is close". Reindeer and northern lights were popular. In general, winter was not 
the favorite season; only six winter photos were chosen, but winter photos were also a minority in the whole selection. One interviewee said that she likes winter, and another very keen fisher said that she liked fishing in winter as well as in summer. Northern nature seemed to be more familiar to those who had, for example, a Finnish spouse or friends in the community.

Hiking, swimming, running, photographing, cross country skiing and skating were mentioned as activities in nature. However, picnicking and eating out with friends or family received the most mentions (seven mentions) of individual activities.

The selection by a group of young Afghan boys drew our attention because almost all of them chose beautiful nature photos without people and said that nature is important for them. Sunsets, the awakening of nature in spring time and visits to forests, in addition to swimming and sauna, were mentioned as great experiences. On the whole, nature and the Finnish way of using nature seemed to be more familiar to this group than to other groups. They were different in comparison to the other groups in that they were younger and that they lived deeper in the countryside than most of the others.

In the use of natural products, berry picking, mushroom picking and fishing received the most mentions. Bilberries were the most popular of the berries and only one individual said that he had picked cloudberries - an activity which is most appreciated by the original locals in Lapland. Two of the interviewees had picked berries in their country of origin but for many it resembled fruit picking which was a more familiar activity from their childhood.

\section{Nature photos reflecting the state of mind and dreams}

Nature photos raised many kinds of emotions. Relaxation and good feeling were among the positive emotions. These aspects were mentioned many times: "Nature helps us to breath", said one young interviewee. On the other hand, nature was seen as a place where one can relieve the pain and banish other people: "Especially if I am in a bad mood, I go to nature to calm down and to relax", said one individual who chose a picture of a seashore. The bright forest picture, in turn, is comforting when "I have a feeling that this summer people have behaved badly and my incompetence in language has been exploited". A photo of a mire in autumn gives one interviewee a feeling that she would like to be alone in that place; she says that she easily gets tired and bored in the noisy company of other people.

Dreams of home and houses were an important part of the meanings of the images. This was symbolised, for example, by the laundry drying outside a house or a palace in the middle of a park. One interviewee who chose the picture of the palace joked that: "When I came to Europe I thought that I can live in a house like that but, now I live in a standard apartment block on the fourth floor without an elevator".

\section{Conclusion}

The immigrants' photo choices show that their original home country is with them in many ways. The greenness, fertility, rural livelihoods and life close to nature are emphasised. There is a lot of nostalgia: interviewees recall how "the sun shines all the time in my home country and the climate 
is good", or that "I have a longing for trips to nature with my family". When talking about Finland, forests and peacefulness are emphasised. In addition, safety and the possibility to walk outside are related to Finland.

In relationships to nature, there does not seem to be clear differences between those whose origins are in the countryside or those whose origins are in cities, although nomadism, cultivation and domestic animals are naturally more typically a part of the lives of those coming from rural environments.

Since only eight of the interviewees had come to Finland before 2014, this means that at the time of the interviews 55 interviewees had been in Finland for a fairly short time, no more than four years. Due to that, it is no wonder that Finnish nature was not familiar to them. Nevertheless, northern nature raises a lot of curiosity and interest. Partly, this interest is similar to that of tourists; the places are seen through the eyes of the stranger, and the northern lights and reindeer are fascinating. It also became clear that contacts with the locals help one in getting to know nature and in collecting and utilising nature's offerings. These local contacts seem to be almost as rare as they are among tourists who are also eager to seek them and to 'live like a local'.

The results of this approach support the results of earlier studies in that sociality seems to be important in the use of nature, and that gardens, parks and built environments are at least as important as 'wild' nature. The passive use and admiration of nature are common. Still, active ways of using nature also exist. For many, nature was a place to reflect feelings and also to combine experiences from their earlier life history with the new situation. Previous knowledge of animals and plants was adjusted to the new living environments and the new natural phenomena created similar types of excitement and astonishment which tourists have when they enter new countries.

The great variety of immigrants' experiences of nature could be a richness for Finnish culture. Recognising and sharing these different kinds of biographies and knowledges could strengthen both the immigrants' own understanding of the role of nature in their life history and the Finnish communities' acceptance and understanding of the new residents' relationships to nature. Not many Finns have experiences of nomadism or hunting falcons and they have little knowledge of how different the experiences of the newcomers can be. That might also give some understanding of the tourists' relationships to nature coming from a far. For the immigrants, the knowledge of the nature of the present home country would help them attach to local communities.

\section{References}

Buijs, A. E., Elands, B. H., \& Langers, F. (2009). No wilderness for immigrants: Cultural differences in images of nature and landscape preferences. Landscape and Urban Planning, 91(3), 113-123. https://doi.org/10.1016/j.landurbplan.2008.12.003

Faehnle, M., Jokinen, J., Karlin, A., \& Lyytimäki, J. (2010). Kaupunkiluonto ja monikulttuurisuusmaahanmuuttajat luontoalueiden kokijoina ja käyttäjinä. (Suomen Ympäristö 1/2010.) Helsinki: Suomen ympäristökeskus. 
Flint, C. G., Kunze, I., Muhar, A., Yoshida, Y., \& Penker, M. (2013). Exploring empirical typologies of human-nature relationships and linkages to the ecosystem services concept. Landscape and Urban Planning, 120, 208-217. https://doi.org/10.1016/j.landurbplan.2013.09.002

Gentin, S. (2011). Outdoor recreation and ethnicity in Europe - A review. Urban Forestry \&Urban Greening, 10(3), 153-161. https://doi.org/10.1016/j.ufug.2011.05.002

Harper, D. (2002). Talking about pictures: A case for photo elicitation. Visual Studies, 17(1), 13-26. https://doi.org/10.1080/14725860220137345

Huttunen, L. (2002). Kotona, maanpaossa, matkalla: Kodin merkitykset maahanmuuttajien omaelämäkerroissa. Helsinki: Suomalaisen Kirjallisuuden Seura.

Pitkänen, K., Oratuomi, J., Hellgren, D., Furman, E., Gentin, S., Sandberg, E., Hellgren, Ø., \& Krange, O. (2017). Nature-based integration: Nordic experiences and examples. Nordic Council of Ministers (TemaNord 2017:517.) Retrieved from https://norden.diva-portal.org/smash/get/ diva2:1099117/FULLTEXTo1.pdf

Rossi, L. (2010). Yksilöllä on väliä ympäristön kannalta: Miten voisi tutkia yksilön elinikäistä ympäristösuhdetta. Elore 17(2). Retrieved from http://www.elore.fi/arkisto/2_10/rossi_2_10. pdf

Siim, P. (2006). Paikkasuhteet maahanmuuttajien kertomuksissa. In S. Knuuttila, P. Laaksonen, \& U. Piela (Eds.), Paikka: Eletty, kuviteltu, kerrottu (pp. 93-119). Helsinki: Suomalaisen Kirjallisuuden Seura.

Stodolska, M., Peters, K. \& Horolets, A. (2017). Immigrants' adaptation and interracial/interethnic interactions in natural environments. Leisure Sciences, 39, 475-491. https://doi.org/10.1080/ 01490400.2016 .1213676

Willamo, R. (2005). Kokonaisvaltainen lähestymistapa ympäristönsuojelutieteessä: Sisällön moniulotteisuus ympäristönsuojelijan haasteena. (Environmentalica Fennica 23.) Helsingin yliopisto. Retrieved from https://helda.helsinki.fi/bitstream/handle/10138/22238/kokonais.pdf?sequence $=1$ \&isAllowed $=\mathrm{y}$

Özgüner, H. (2011). Cultural differences in attitudes towards urban parks and green spaces. Landscape Research, 36, 599-620. https://doi.org/10.1080/01426397.2011.560474 